\title{
Overgang van de prepack naar een bruikbaar(der) instrument
}

\section{Over de huidige relevantie van de prepack en overgang van onderneming in faillissement}

$$
\text { Mr. H.J. de Kloe* }
$$

In deze bijdrage wordt onderzocht of de prepack na Smallsteps nog relevant is voor de praktijk. Daarnaast wordt ingegaan op een mogelijke oplossing om de prepack weer relevant te maken: toepassing van de OVO-regeling op alle doorstarts in faillissement. Deze mogelijkheid wordt onderzocht met behulp van een vergelijking met Engels recht.

\section{Inleiding}

In juni 2015 is het wetsvoorstel Wet continuïteit ondernemingen I (WCO I) ingediend bij de Tweede Kamer. ${ }^{1}$ De WCO I beoogt een wettelijke basis te geven aan de zogeheten prepack, in de memorie van toelichting ook wel angeduid als 'stille voorbereidingsfase'. ${ }^{2}$ Ondernemers bij wie een faillissementstoestand dreigt, kunnen de rechtbank verzoeken een of meer personen aan te wijzen die bij een faillietverklaring aangesteld worden als curator (art. 363 lid 1 Faillissementswet (Fw) (nieuw)). ${ }^{3}$ Deze beoogd curator kan het faillissement voorbereiden onder toezicht van een beoogd rechter-commissaris. De beoogd curator zal in de regel onder meer onderzoeken of een doorstart tot de mogelijkheden behoort.

Medio 2017 oordeelde het Hof van Justitie van de Europese Unie (hierna: Hof van Justitie) in het Smallsteps-arrest dat de regels met betrekking tot overgang van onderneming (onder omstandigheden) van toepassing zijn als aan een doorstart tijdens faillissement een stille voorbereidingsfase vooraf is gegaan. ${ }^{4}$ De minister voor Rechtsbescherming is van mening dat Smallsteps niet in de weg staat aan de verdere behandeling van de WCO I. Volgens de minister zijn er nog steeds situaties waarin een stille voorbereidingsfase op het faillissement van toegevoegde waarde kan zijn, ook als bij een eventuele doorstart de werknemers in beginsel overgaan op de verkrijger. ${ }^{5}$ Het is de vraag of behoefte bestaat aan de aanstelling van een

Mr. H.J. de Kloe is wetenschappelijk docent ondernemingsrecht en financieel recht bij de sectie Handels- en Ondernemingsrecht \& Financieel Recht van de Erasmus School of Law te Rotterdam.

De tekst voor deze bijdrage is afgesloten per 10 april 2019.

1. Kamerstukken II 2014/15, 34218, 2.

2. Kamerstukken II 2014/15, 34218, 3 .

3. Voor het (meest recente) gewijzigde voorstel van wet dat bij de Eerste Kamer is ingediend, zie Kamerstukken II 2015/16, 34218, A.

4. HvJ EU 22 juni 2017, ECLI:EU:C:2017:489.

5. Kamerstukken II $2017 / 18,34218$, J. beoogd curator, als bij een daaropvolgende doorstart alle werknemers overgaan op de verkrijger, terwijl dat niet het geval is bij een doorstart die niet geprepackt is.

In de literatuur en praktijk wordt gepleit voor toepassing van de regeling met betrekking tot overgang van onderneming (hierna: OVO en OVO-regeling) in faillissement, mede omdat de prepack daarmee weer relevant wordt voor de praktijk. ${ }^{6}$ De minister heeft als reactie hierop begin 2019 aangegeven dat hij met nieuwe wetgeving wil komen om overgang van onderneming in faillissement te regelen. Hij wil op korte termijn een voorontwerp voor een dergelijke wet publiceren. Overigens geeft de minister aan dat deze wetgeving losstaat van het verzoek aan de Eerste Kamer om het wetsvoorstel WCO I zo snel mogelijk te behandelen. ${ }^{7}$ Desondanks is de behandeling van de WCO I in de Eerste Kamer aangehouden in afwachting van de OVO-regeling in faillissement. ${ }^{8}$

In deze bijdrage wordt onderzocht of de prepack na Smallsteps nog relevant is voor de praktijk. Is het inderdaad, zoals de minister stelt, zinvol om de WCO I aan te nemen zolang de OVO-regeling niet van toepassing is in faillissement, terwijl deze regeling in beginsel wel van toepassing is op de prepack? Daarnaast wordt ingegaan op een mogelijke oplossing om de prepack weer relevant te maken: toepassing van de OVOregeling op alle doorstarts in faillissement. Met behulp van een vergelijking met Engels recht worden knelpunten gesignaleerd bij toepassing van de OVO-regeling in faillissement. Ook worden mogelijkheden besproken om deze knelpunten weg te

6. Bijv. N.M.Q. van der Neut, Pre-pack is overgang van onderneming: hoe nu verder?, TRA 2017/88; W.H.A.C.M. Bouwens, Het voetspoor van Smallsteps, TvI 2018/4; P. Hufman, Overgang van onderneming bij de pre-pack: een blik vooruit, TvO 2017, afl. 4, p. 183-188; L.G. Verburg, Smallsteps: en hoe nu verder?, in: E.J.R. Verwey, M.A. Broeders \& Ph.W. Schreurs (red.), De curator en het personeel (INSOLAD Jaarboek 2018), Deventer: Wolters Kluwer 2018, p. 119-142. Zie verder de brieven van de adviescommissie insolventierecht en arbeidsrecht van de Nederlandse Orde van Advocaten (NOvA) d.d. 19 oktober 2017 en FNV en CNV van 17 oktober 2017, bijlagen bij Kamerstukken II 2017/18, 34218, I. Overigens is de NOvA in het geheel niet positief over de prepack.

7. Kamerstukken I 2018/19, 34218, K.

8. Zie www.eerstekamer.nl/korteaantekening/20190129_j_v?dossier= vjulnplqjqxe, laatst geraadpleegd op 10 april 2019. 


\section{Maandblad}

Ondernemingsrecht

nemen in de wettelijke regeling die de minister wil realiseren. $\mathrm{Bij}$ de vergelijking met Engels recht wordt de administration als uitgangspunt genomen, omdat een doorstart in Engeland veelal vanuit administration plaatsvindt.

De opzet is als volgt. Paragraaf 2 geeft een schets van de achtergrond van de prepack en de WCO I en het belang van de prepack voor de praktijk. In paragraaf 3 wordt ingegaan op de OVO-regeling, het Smallsteps-arrest en de gevolgen van deze uitspraak voor de prepack. In de vierde paragraaf wordt ingegaan op de vraag of de prepack na Smallsteps nog relevant is voor de praktijk. De Engelse OVO-regeling in administration wordt in paragraaf 5 geschetst. In paragraaf 6 wordt besproken welke knelpunten er zijn voor toepassing van de OVOregeling op Nederlandse faillissementen. Ook worden mogelijke oplossingen geboden. De bijdrage sluit in paragraaf 7 af met een conclusie.

\section{Achtergrond prepack en belang praktijk}

\subsection{Ontstaan prepack}

In 2011 deed Tollenaar de oproep om de prepack naar Engels voorbeeld in Nederland te introduceren, mede om te voorkomen dat ondernemers in financiële moeilijkheden hun centrum van voornaamste belangen (COMI) ${ }^{9}$ verplaatsen naar het Verenigd Koninkrijk om daar gebruik te maken van de prepack. ${ }^{10}$ De roep om de komst van de prepack heeft, al dan niet in de door Tollenaar voorgestane vorm, weerklank gevonden in de praktijk ${ }^{11}$ en in de literatuur. ${ }^{12}$ Vanaf 2012 heeft de prepack zich ontwikkeld in de praktijk. Ondanks dat een wettelijke basis ontbreekt, benoemden acht van de elf rechtbanken beoogd curatoren en beoogd rechters-commissarissen. ${ }^{13}$ In het merendeel van de gevallen werd de stille voorbereidingsfase gebruikt om een doorstart voor te bereiden. ${ }^{14}$

9. Op grond van art. 3 IVO mag een rechter van een lidstaat uitsluitend een hoofdprocedure openen als het centrum van voornaamste belangen (in het Engels: centre of main interests, COMI) in die lidstaat is gelegen.

10. N.W.A. Tollenaar, Faillissementsrechters van Nederland: geef ons de pre-pack!, TvI 2011/23.

11. Tijdens een seminar in 2012 over de prepack in Nederland was een panel van vijf personen unaniem van mening dat de prepack een waardevolle toevoeging is aan de Nederlandse faillissementspraktijk, zie K. Kele \& P. Wolterman, Verslag seminar 'De Nederlandse pre-pack - ready for take-off?' 11 april te Amsterdam, TvI 2012/31. Zie ook K. Beke \& P. Wolterman, Wijs bij bankroet curator in stilte aan, Het Financieele Dagblad 3 mei 2012, p. 9

12. Zie onder meer H. Koster, Herstructureringen bij insolventie: naar de pre-pack plus!, TvI 2013/7; E. Loesberg, Pre-packs in het Nederlandse faillissementsrecht. Heiligt het doel de middelen?, TOP 2013, afl. 1, p. 29-31; J.L.R.A. Huydecoper, Pre pack liquidatie: wat vindt een betrekkelijke buitenstaander daar op het eerste gezicht van?, TvI 2013/5.

13. J.R. Hurenkamp, Failliet of fast forward? Een analyse van de pre-pack in de praktijk, TvI 2015/20. Zie ook Kamerstukken I 2016/17, 34218, C, p. 1.

14. M.R. van Zanten, It takes Smallsteps to pre-pack, in: E.J.R. Verwey, M.A. Broeders \& Ph.W. Schreurs (red.), De curator en het personeel (INSOLAD Jaarboek 2018), Deventer: Wolters Kluwer 2018, p. 50-52; Hurenkamp 2015, par. 4.2.
Op 22 oktober 2013 is het voorontwerp voor de WCO I ter internetconsultatie aangeboden. Het wetsvoorstel is 4 juni 2015 aangeboden aan de Tweede Kamer. De WCO I beoogt een wettelijke basis te bieden voor de stille voorbereidingsfase. In de memorie van toelichting wordt het voorbereiden van een doorstart prominent genoemd als doel van de stille voorbereidingsfase. ${ }^{15}$ De toelichting noemt daarnaast als mogelijkheid dat de stille voorbereidingsfase (slechts) wordt gebruikt door de beoogd curator om zich 'in te lezen' voor het aanstaande faillissement. ${ }^{16}$ De beoogd curator dient zijn rol in overleg met de schuldenaar in te vullen. In beginsel bereidt de schuldenaar het faillissement voor en kijkt de curator kritisch mee over de schouder van de schuldenaar, maar de beoogd curator kan met toestemming van de schuldenaar ook derden bevragen en deskundigen inschakelen (art. 364 lid $4 \mathrm{Fw}$ (nieuw)). ${ }^{17}$ Wordt een doorstart voorbereid, dan moet de beoogd curator erop toezien dat actief gezocht wordt naar overnamekandidaten. ${ }^{18}$ De beoogd curator kan de rechtbank verzoeken de stille voorbereidingsfase te beëindigen als de schuldenaar niet met hem of haar meewerkt (art. 366 Fw (nieuw)). ${ }^{19}$ Met de aanwijzing van een beoogd curator wordt ook een beoogd rechter-commissaris aangewezen. De beoogd rechter-commissaris houdt toezicht op de beoogd curator (art. 365 lid 2 Fw (nieuw)).

\subsection{Belang prepack voor en in de praktijk}

De voordelen die toegeschreven worden aan de prepack, zien grotendeels op het realiseren van een hogere verkoopprijs voor de onderneming en meer behoud van werkgelegenheid. ${ }^{20}$ Het is de vraag of deze voordelen ook daadwerkelijk worden behaald. In een onderzoek naar de Nederlandse prepack tussen begin 2012 en medio 2014 komt Van den Bosch inderdaad tot de conclusie dat significant meer werkgelegenheid (18\%) behouden blijft bij toepassing van een prepack ten opzichte van een normale doorstart. Wat betreft de verkoopprijs en de uitkering aan concurrente schuldeisers komt Van den Bosch echter tot de conclusie dat er geen significant

15. Kamerstukken II 2014/15, 34218, 3, p. 5 en 6

16. Kamerstukken II 2014/15, 34218, 3, p. 18.

17. Zie over de positie van de beoogd curator in het wetsvoorstel M.R. van Zanten, De beoogd curator, uitgegroeid van fly on the wall tot spin in het web, TvI 2015/35.

18. Kamerstukken II $2014 / 15,34218,3$, p. 17-19.

19. Kamerstukken II 2014/15, 34218, 3, p. 20.

20. F.M.J. Verstijlen, Reorganisatie van ondernemingen en pre-pack, in: H.J de Kluiver (red.), Wet continuïteit ondernemingen (delen I en II) en het bestuursverbod (Preadviezen Vereeniging 'Handelsrecht' 2014), Zutphen: Uitgeverij Paris 2014, p. 28, 55 en 56; J.J. van Hees, Stille bewindvoering: pre-packen en wegwezen?, Ondernemingsrecht 2014/79; M.R. van Zanten, Aan het werk met de pre-pack!, ArbeidsRecht 2013/47; Kamerstukken I 2016/17, 34218, C, p. 1 en 2; Kamerstukken II 2014/15, 34218, 3, p. 9-10 en 27-28. Zie ook art. 363 lid 1 Fw (nieuw), waarin staat dat meerwaarde van de prepack aanwezig wordt geacht als de stille voorbereidingsfase de kans op verkoop voor een zo hoog mogelijke prijs en met behoud van zo veel mogelijk werkgelegenheid zodanig kan vergroten, dat dit opweegt tegen het nadeel dat de voorbereiding van het faillissement in stilte plaatsvindt. 
verschil bestaat tussen de doorstart mét en zonder stille voorbereidingsfase. $^{21}$

Het lijkt erop dat ten aanzien van de prepack in het Verenigd Koninkrijk dezelfde conclusies getrokken kunnen worden. In een onderzoek naar de prepack tussen september 2001 en september 2004 komt Frisby tot de conclusie dat de prepack zorgt voor meer behoud van werkgelegenheid. ${ }^{22}$ Graham komt, op basis van onderzoek dat is uitgevoerd door de University of Wolverhampton, voorzichtig tot dezelfde conclusie. $^{23}$ Uit dezelfde onderzoeken lijkt te volgen dat de prepack ook in het Verenigd Koninkrijk niet leidt tot een hogere verkoopopbrengst. Uit het onderzoek van Frisby volgt dat de prepackaged administration niet zorgt voor een hogere procentuele uitkering aan de schuldeisers. ${ }^{24}$ Daarnaast volgt uit het Wolverhampton-onderzoek dat in 52\% van de onderzochte administrations die niet zijn voorbereid geen uitkering werd gedaan aan concurrente schuldeisers, ten opzichte van $58 \%$ van de onderzochte prepacks. ${ }^{25}$

Op basis van de uitkeringen aan concurrente schuldeisers kan echter niet de conclusie worden getrokken dat de prepack niet zorgt voor een hogere verkoopprijs. Het is namelijk ook mogelijk dat een eventueel hogere verkoopprijs ten goede komt aan zekerheidsgerechtigde schuldeisers, ten koste van concurrente schuldeisers. ${ }^{26}$ Dit wordt overigens weersproken door een onderzoek dat is gedaan met behulp van de dataset die Frisby heeft gebruikt voor haar onderzoek. Hieruit volgt dat er geen significant verschil tussen de prepack en een 'gewone' administration is wat betreft de uitkering aan zekerheidsgerechtigde

21. S.F.W. van den Bosch, De pre-pack in de Nederlandse praktijk: een empirisch onderzoek vanuit economisch perspectief, TvOB 2018, afl. 4, p. 86-96.

22. S. Frisby, A preliminary analysis of pre-packaged administrations, Londen: R3 2007, p. 69-71. Van de onderzochte zaken waar informatie bekend was over behoud van werkgelegenheid, werden bij prepacks in $92 \%$ van de gevallen alle banen behouden, tegenover $65 \%$ van de gevallen waarbij geen sprake was van een prepack. Dat in het Verenigd Koninkrijk vaak alle banen behouden blijven, komt doordat de OVOregeling ook in de administration van toepassing is, zie hiervoor par. 5 .

23. T. Graham, Review into Pre-pack Administration, juni 2014, www.gov. uk/government/publications/graham-review-into-pre-packadministration, p. 25 en 26. Zie ook P. Walton \& C. Umfreville, Prepack empirical research: Characteristic and outcome analysis of pre-pack administration, Wolverhampton: Wolverhampton University 2014 p. 26 en 27 (hierna: Wolverhampton 2014). In 81,74\% van de prepackzaken waar informatie over behoud van werkgelegenheid bekend was, werden alle banen behouden. Het is de vraag of deze conclusie op basis van het verrichte onderzoek getrokken kan worden, omdat op het punt van behoud van werkgelegenheid geen vergelijking is gemaakt met administrations die niet zijn geprepackt.

24. Frisby 2007. Frisby heeft zowel voorverpakte administrative receiverships als administrations onderzocht. Bij beide procedures was de uitkering aan alle schuldeisers $22 \%$ bij een prepack, tegenover $21,8 \%$ zonder prepack (p. 50). Bij uitsluitend de administrations was de uitkering aan alle schuldeisers $22,7 \%$ bij een prepack, tegenover $22,8 \%$ zonder prepack (p. 59).

25. Wolverhampton 2014, p. 32 en 65. Vgl. Graham 2014, p. 33, waar op basis van het Wolverhampton-rapport om voor mij onverklaarbare redenen andere percentages genoemd worden. Volgens Graham werd in 56\% van de 'gewone' administrations geen uitkering gedaan aan concurrente schuldeisers, tegenover $60 \%$ van de prepacks. schuldeisers en (na het weglaten van een uitzonderlijk faillissement) concurrente schuldeisers. ${ }^{27}$

Dat uit empirisch onderzoek lijkt te volgen dat de prepack neutraal is voor de gezamenlijke schuldeisers maar positief voor werknemers, is een reden om het gebruik van de prepack te stimuleren. ${ }^{28}$ Tot op heden is de prepack in Nederland echter een marginaal verschijnsel. Uit onderzoek van Van Zanten volgt dat in 2013 het vaakst een beoogd curator is aangewezen, namelijk 37 keer. $^{29}$ Volgens het CBS zijn in hetzelfde jaar 9345 bedrijven failliet gegaan en hebben 3300 doorstarts plaatsgevonden. ${ }^{30}$ Ervan uitgaande dat alle stille voorbereidingsfases zijn uitgemond in een doorstart, ${ }^{31}$ is op het hoogtepunt van de prepack aan slechts $1,1 \%$ van de doorstarts een stille voorbereidingsfase voorafgegaan. Ter vergelijking: in het Verenigd Koninkrijk was in 2017 28\% van de administrations geprepackt. $^{32}$

Vanaf 2014 is het aantal stille voorbereidingsfases zowel in absolute als in relatieve zin ieder jaar afgenomen. Van Zanten vermoedt dat de verminderde populariteit samenhangt met de procedure die door de vakbond FNV en CNV is gestart naar aanleiding van de doorstart van Heiploeg ${ }^{33}$ en de procedure die FNV is gestart naar aanleiding van de doorstart van

26. Frisby concludeert dat er indicaties zijn die hierop wijzen, hoewel op basis van haar onderzoek geen harde conclusies getrokken kunnen worden, zie Frisby 2007, p. 67. Zie voor een vergelijking tussen onder meer de positie van zekerheidsgerechtigde crediteuren bij prepacks in het Verenigd Koninkrijk en Nederland: A. Kastrinou \& S.V. Vullings, 'No evil is without good': A comparative analysis of pre-pack sales in the UK and the Netherlands, International Insolvency Review 2018, afl. 3, p. 320-339.

27. A. Polo, Secured creditor control in bankruptcy: Costs and conflict, working paper 2012, https://papers.ssrn.com/sol3/papers.cfm?abstract_ $\mathrm{id}=2084881$ (laatst geraadpleegd op 10 april 2019).

28. Lidstaten van de EU worden ook - deels op andere gronden - gestimuleerd om de prepack op te nemen in wetgeving door de European Law Institute, zie B. Wessels \& S. Madaus, Rescue of business in insolvency law, Wenen: ELI 2017, p. 302 (recommendation 7.03).

29. Van Zanten 2018, p. 48.

30. L. Hoekema, A.P. Alberda \& A. Boutorat, Doorstart na faillissement fase I, Heerlen: CBS 2017, p. 17. Zowel Van Zanten als het CBS telt het faillissement van een groep als één faillissement.

31. Wat niet het geval is, omdat een klein deel van de prepacks die Van Zanten heeft meegerekend niet zijn uitgemond in een faillissement. Daarnaast heeft in de periode van juli 2012 t/m mei 2017 in 88\% van de faillissementen die volgden op een stille voorbereidingsfase een doorstart plaatsgevonden. Zie hiervoor Van Zanten 2018.

32. Pre Pack Pool, Annual Review 2017, p. 5 (www.prepackpool.co.uk/ uploads/files/documents/Pre-pack-Pool-Annual-Review-2017.pdf). In het Verenigd Koninkrijk werden in 20171289 administrations geopend, waarvan 356 geprepackt. Overigens is het aantal prepacks ook in het Verenigd Koninkrijk beperkt als het afgezet wordt tegen alle insolventieprocedures. In 2017 werd ten aanzien van 17.243 ondernemers een insolventieprocedure geopend (The Insolvency Service, Insolvency Statistics - October to December 2017 (Q4 2017), p. 3 (www.gov.uk/ government/statistics/insolvency-statistics-october-to-december-2017). Hieruit volgt dat $2,1 \%$ van de insolventieprocedures volgde op een stille voorbereidingsfase, tegenover $0,4 \%$ in Nederland.

33. Zie hiervoor het persbericht van FNV, Vakbonden dagen garnalenverwerker Heilploeg voor de rechter, fnv.nl 21 juli 2014. 


\section{Maandblad \\ Ondernemingsrecht}

Estro. ${ }^{34}$ Op 22 juni 2017 heeft het Hof van Justitie arrest gewezen in de Estro/Smallsteps-zaak. Voor zover ik kan nagaan, zijn daarna slechts twee faillissement uitgesproken waaraan een stille voorbereidingsfase is voorafgegaan. ${ }^{35}$ In de eerste plaats betreft dit het faillissement van Bogra B.V. en een aantal tot dezelfde groep behorende vennootschappen. De Rechtbank Noord-Holland gaf op 21 juni 2017 aan wie de beoogd curator en beoogd rechter-commissaris waren. Op 22 juni 2017 is een overeenkomst tot 'stille bewindvoering'36 gesloten die, vermoedelijk (mede) vanwege de op die dag gewezen Smallsteps-uitspraak, per 23 juni 2017 is beëindigd. ${ }^{37}$ Het tweede faillissement waaraan een stille voorbereidingsfase vooraf is gegaan, is het faillissement van SecurCash. De stille voorbereidingsfase is gebruikt om in overleg met onder meer De Nederlandsche Bank te komen tot een gecontroleerde afbouw in faillissement, zodat het betalingsverkeer en de veiligheid van winkeliers zo min mogelijk in gevaar zouden komen. ${ }^{38}$ Het is mijn inschatting dat er voor het overige geen of nauwelijks verzoeken meer worden gedaan tot aanwijzing van een beoogd curator vanwege onduidelijkheid over de reikwijdte van het Smallsteps-arrest. ${ }^{39}$ Daarnaast is het denkbaar dat rechtbanken terughoudend zijn bij het aanwijzen van beoogd curatoren en beoogd rechters-commissarissen, omdat in de literatuur gewezen is op het risico van staatsaansprakelijkheid wegens onjuiste implementatie van de OVO-richtlijn ten aanzien van prepacks. ${ }^{40}$

\section{Smallsteps, discussie over de reikwijdte en uitwerking in lagere rechtspraak}

Voordat ik de Smallsteps-uitspraak bespreek en inga op verschillende standpunten in de literatuur over de reikwijdte van

34. Van Zanten 2018, p. 49. Zie de persberichten van FNV, FNV overweegt juridische stappen richting Estro/Smallsteps, fnv.nl 25 juli 2014, en FNV dagvaardt Smallsteps (voormalig Estro) samen met oud-medewerkers, fnv.nl 30 januari 2015.

35. Dit ben ik nagegaan door op 10 april 2019 op www.failimprove.nl faillissementsverslagen te doorzoeken op de zoektermen 'pre-pack', 'pre pack', 'beoogd curator' en 'beoogd curatoren'.

36. Volgens de MvT bij de WCO I is 'stille bewindvoerder' (en daarmee ook 'stille bewindvoering') een verwarrende term, omdat de term 'bewindvoerder' een verandering in de beheers- en beschikkingsbevoegdheid van de schuldenaar impliceert. Zie Kamerstukken II 2014/15, 34218, 3, p. 23.

37. Zie hiervoor het tweede openbare faillissementsverslag inzake Bogra B.V., p. 5.

38. Zie het eerste openbare faillissementsverslag inzake SecurCash Nederland B.V. onder 6 (Voortzetten/doorstart onderneming) en J. Leijten, Toen de geldwagens opeens niet meer reden. Reconstructie bankroet SecurCash, NRC 16 maart 2019, p. E12 en E13.

39. Zie ook Rb. Noord-Holland 12 oktober 2017, ECLI:NL:RBNHO: 2017:8423, r.o. 5.15: 'Het is denkbaar dat nader onderzoek naar en bespreking over een pre-pack niet van de grond zijn gekomen of zijn gestaakt in verband met de Smallsteps-uitspraak van 22 juni 2017.'

40. J.R. Hurenkamp, Ondergang van onderneming door de pre-pack?, TvI 2017/21. Anders onder meer P.R.W. Schaink, Het arrest van het Hof van Justitie inzake FNV c.s./Smallsteps, TvI 2017/22 en R.C.M. van Moorsel, Food for thought. Over het dwingende arrest van het Hof van Justitie inzake FNV c.s./Smallsteps, TvI 2017/32. Zie voor vragen over staatsaansprakelijkheid van de vaste commissie voor Justitie en Veiligheid en het antwoord van de minister hierop Kamerstukken I 2018/19, 34218 , K.
Smallsteps en de toepassing van dit arrest in de lagere rechtspraak, geef ik voor de volledigheid eerst het wettelijk kader weer dat van toepassing is op een overgang van onderneming.

\subsection{Overgang van onderneming}

In 1977 zag de eerste OVO-richtlijn het licht. ${ }^{41}$ In 1981 werd de richtlijn geïmplementeerd in artikel 1639aa-dd Burgerlijk Wetboek (BW). ${ }^{42}$ Met de verplaatsing van de regels over de arbeidsovereenkomst is de OVO-regeling terechtgekomen in artikel 7:662-666 BW. Zeer kort gezegd houdt de regeling in dat werknemers bij een overgang van onderneming van rechtswege in dienst treden bij de verkrijger van de onderneming met behoud van hun rechten en plichten. Een recht dat werknemers onder meer behouden, is het recht op betaling van vorderingen (zoals achterstallig loon) die voor de overgang zijn ontstaan.

In het Abels-arrest uit 1985 oordeelde het Hof van Justitie dat de OVO-regeling niet van toepassing is als de vervreemder in staat van faillissement is verklaard en de over te dragen onderneming tot de boedel behoort. ${ }^{43}$ Het Hof overwoog daarbij dat het lidstaten vrijstaat om de regeling ook tijdens faillissement van de vervreemder van toepassing te laten zijn. ${ }^{44} \mathrm{Bij}$ een overgang tijdens surseance van betaling is de OVO-regeling wel van toepassing, omdat de surseance ziet op behoud van de boedel en voortzetting van de onderneming. ${ }^{45}$ De Hoge Raad oordeelde twee jaar later in het Happé/Scheepstra-arrest dat de OVO-regeling ook in Nederland niet van toepassing is bij het faillissement van de vervreemder. ${ }^{46}$ Sinds de verplaatsing van het arbeidsrecht naar Boek 7 BW in 1997 is deze regel gecodificeerd in artikel 7:666 BW. ${ }^{47}$

Nadien is de richtlijn van 1977 in 1998 gewijzigd $^{48}$ en is in 2001 een nieuwe richtlijn vastgesteld. ${ }^{49}$ In 1998 werd het huidige artikel 5 aan de richtlijn toegevoegd. In dit artikel is opgenomen dat de OVO-regeling niet van toepassing is op een overgang van onderneming wanneer 'de vervreemder verwikkeld is in een faillissementsprocedure of in een soortgelijke procedure met het oog op de liquidatie van het vermogen van de vervreemder onder toezicht van een bevoegde overheidsin-

41. Richtlijn $77 / 187 /$ EEG van de Raad van 14 februari 1977 inzake de onderlinge aanpassing van de wetgevingen der Lid-Staten betreffende het behoud van de rechten van de werknemers bij overgang van ondernemingen, vestigingen of onderdelen daarvan.

42. Stb. 1981, 400 .

43. HvJ EG 7 februari 1985, NJ 1985/900.

44. HvJ EG 7 februari 1985, NJ 1985/900, r.o. 24

45. HvJ EG 7 februari 1985, NJ 1985/900, r.o. 28.

46. HR 30 oktober 1987, NJ 1988/191.

47. Stb. 1996, 406.

48. Richtlijn 98/50/EG van de Raad van 29 juni 1998 tot wijziging van Richtlijn 77/187/EEG inzake de onderlinge aanpassing van de wetgeving der lidstaten betreffende het behoud van de rechten van de werknemers bij overgang van onderneming, vestigingen of onderdelen van vestigingen.

49. Richtlijn 2001/23/EG van de Raad van 12 maart 2001 inzake de onderlinge aanpassing van de wetgevingen der lidstaten betreffende het behoud van de rechten van de werknemers bij overgang van ondernemingen, vestigingen of onderdelen van ondernemingen of vestigingen. 
stantie'. Lidstaten mogen bepalen dat de OVO-regeling ook bij faillissement van de vervreemder van toepassing is. Als een lidstaat de OVO-regeling ook van toepassing verklaart als de vervreemder in een insolventieprocedure is verwikkeld, kan die lidstaat op grond van artikel 5 lid 2 van de OVO-richtlijn bepalen dat de verkrijger niet aansprakelijk is voor schulden die voor de overgang zijn ontstaan, en/of dat arbeidsvoorwaarden onder omstandigheden in overleg met vertegenwoordigers van de werknemers gewijzigd kunnen worden.

Nederland heeft geen gebruik gemaakt van de mogelijkheid die artikel 5 lid 2 van de OVO-richtlijn biedt. Artikel 7:666 BW bepaalt nog steeds dat de OVO-regeling niet van toepassing is bij faillissement van de vervreemder. In de toelichting op het wetsvoorstel WCO I stelde de minister zich op het standpunt dat de OVO-regeling ook niet van toepassing is op een faillissement waaraan een stille voorbereidingsfase was voorafgegaan. ${ }^{50}$ Voor indiening van het wetsvoorstel bij de Tweede Kamer bestond hierover geen overeenstemming in de literatuur. ${ }^{51}$ Over de betekenis en reikwijdte van het Smallsteps-arrest is discussie in de literatuur, maar het arrest laat in ieder geval zien dat de OVO-regeling onder omstandigheden van toepassing is op een doorstart die is voorbereid in een stille voorbereidingsfase.

\subsection{Smallsteps}

Vanwege de precaire financiële situatie bij onder meer Estro Kinderopvang B.V. heeft de Rechtbank Amsterdam op 10 juni 2014 een beoogd curator aangewezen. Gedurende de stille voorbereidingsfase is met Smallsteps B.V. onderhandeld over een doorstart. Bijna vier weken later, op 5 juli 2015, deed Estro het verzoek haar eigen faillissement uit te spreken. Op dezelfde dag werd de koopovereenkomst getekend door de curator en Smallsteps, waarmee de voorbereide doorstart op de datum van faillissement werd geëffectueerd. ${ }^{52}$ Naar de mening van FNV en een aantal werknemers van Estro was sprake van een overgang van onderneming in de zin van de OVO-richtlijn en de implementatie hiervan in artikel 7:662 e.v. BW, ondanks het feit dat de OVO-regeling op grond van artikel 7:666 BW niet van toepassing is als de overgedragen onderneming tot de boedel van een failliete werkgever behoort. Omdat de discussie ziet op de uitleg van een Europese richtlijn en onduidelijk is of de prepack onder de uitzondering van artikel 5 lid 1 van de OVO-richtlijn valt, stelt de

50. Kamerstukken II 2014/15, 34218, 3, p. 33-35.

51. Op dezelfde lijn als de minister zaten bijv. Van Zanten 2013; L.G. Verburg, De doorstart in faillissement en het debiet van '662', FIP 2014/361; Verstijlen 2014, p. 56-60; P.R.W. Schaink, Werknemers en hun failliete werkgever, door de bril van de doorstarter, TvI 2015/16 Voor andere standpunten, zie onder meer J. van der Pijl, Opvolgend werkgeverschap na een doorstart - een nieuw begin of toch niet? ArbeidsRecht 2013/38, P. Hufman \& I. Zaal, De toepasselijkheid van de Richtlijn overgang van onderneming bij insolvente ondernemingen, TAP 2014/98 en hoofdstuk 5 van de reactie van de NOvA op het ontwerpvoorstel WCO I van 21 januari 2014 (www.internetconsultatie.nl/ wet_continuiteit_ondernemingen_i).

52. Deze feiten zijn te kennen uit Rb. Midden-Nederland 24 februari 2016, JOR 2016/147. rechtbank hierover prejudiciële vragen aan het Hof van Justitie. $^{53}$

Het Hof van Justitie overweegt dat een procedure aan drie voorwaarden moet voldoen om onder de uitzondering van artikel 5 lid 1 van de OVO-richtlijn te vallen. In de eerste plaats moet sprake zijn van een faillissementsprocedure of een soortgelijke procedure. Ten tweede moet deze procedure zijn ingeleid met het oog op de liquidatie van het vermogen van de vervreemder. Tot slot moet de procedure onder toezicht van een overheidsinstantie staan. Aan de eerste voorwaarde is voldaan, maar aan de tweede en derde voorwaarde (onder voorbehoud van verificatie door de verwijzende rechter) niet.

Over de tweede voorwaarde overweegt het Hof dat de prepack in de voorgelegde casus 'tot in de kleinste details de overdracht van de onderneming beoogt voor te bereiden' om de onderneming in faillissement zo snel mogelijk going concern door te starten. Ook als de prepack mede gericht is op een zo hoog mogelijke opbrengst voor de boedel, beoogt de aan de orde gestelde prepack - onder voorbehoud van verificatie door de verwijzende rechter - uiteindelijk niet de liquidatie van de onderneming. Aan de tweede voorwaarde is dus in beginsel niet voldaan. Ook aan de derde voorwaarde is niet voldaan, omdat de stille voorbereidingsfase onder leiding van de schuldenaar staat. Weliswaar worden een beoogd curator en rechter-commissaris aangesteld, maar zij hebben bij gebrek aan een wettelijke regeling geen formele bevoegdheden. Het Hof komt tot de slotsom dat de voorgelegde prepack niet onder de uitzondering van artikel 5 lid 1 van de OVO-richtlijn valt. Dit betekent dat de OVO-regeling van toepassing is op de doorstart van Estro. ${ }^{54}$

\subsection{Betekenis en reikwijdte Smallsteps in de literatuur en lagere rechtspraak}

In de literatuur wordt verschillend gedacht over de betekenis en reikwijdte van het Smallsteps-arrest. Door veel schrijvers wordt ervan uitgegaan dat alle prepacks onder de OVOregeling vallen. Daarbij wordt opgemerkt dat het mogelijk is dat doorstarts die niet onder toeziend oog van een beoogd curator worden voorbereid, ook geraakt kunnen worden door het arrest. ${ }^{55}$ In zijn Kamerbrief van 11 april 2018 sluit ook de minister voor Rechtsbescherming niet uit dat ook de 'gewone' doorstart geraakt wordt door Smallsteps. ${ }^{56}$ Verburg is van mening dat alle prepacks onder de OVO-regeling vallen, maar

53. Rb. Midden-Nederland 24 februari 2016, JOR 2016/147.

54. HvJ EU 22 juni 2017, ECLI:EU:C:2017:489.

55. Zie bijv. de annotatie van Verstijlen onder HvJ EU 22 juni 2017, NJ 2017/369; Schaink 2017; N.M.Q. van der Neut, Pre-pack is overgang van onderneming: hoe nu verder?, TRA 2017/88; Ph.W. Schreurs, Smallsteps en de grote stappen die nu gezet moeten worden, ArA 2017, afl. 3, p. 3-13; Bouwens 2018; J.M.W. Pool, De eerste toepassingen van Smallsteps in Nederland, TvI 2018/39.

56. Kamerstukken II 2017/18, 34218, J, p. 2. 


\section{Maandblad \\ Ondernemingsrecht}

dat de gewone doorstart niet 'in gevaar' komt met Smallsteps. ${ }^{57}$ Anderen gaan uit van een nog beperktere reikwijdte van Smallsteps. Spinath is bijvoorbeeld van mening dat de OVO-regeling in beginsel niet van toepassing is op de prepack, omdat het Hof van Justitie er op basis van de verwijzingsbeslissing ten onrechte van uitgaat dat de prepack gericht is op continuïteit. Daarnaast is het arrest van het Hof naar zijn mening slordig en niet in lijn met eerdere rechtspraak van het Hof. ${ }^{58}$ Het Smallsteps-arrest is naar zijn mening om die reden geen geldend recht. Ook Tollenaar blijft na Smallsteps van mening dat de prepack in Nederland is gericht op opbrengstmaximalisatie voor schuldeisers en niet op continuïteit van de onderneming. ${ }^{59}$

In de lagere rechtspraak wordt het Smallsteps-arrest minder heet gegeten dan het wordt opgediend in een groot deel van de literatuur. De Rechtbank Noord-Holland overweegt in haar beschikking van 12 oktober 2017 expliciet dat de reikwijdte van Smallsteps beperkt is tot een doorstart die tot in detail is voorbereid onder toeziend oog van een beoogd curator en waarbij de doorstart onmiddellijk na faillissement wordt geëffectueerd ${ }^{60}$ In hoger beroep bekrachtigt het Hof Amsterdam de beschikking van de rechtbank met een soortgelijke motivering. ${ }^{61}$ In de Heiploeg-zaak gaat het Hof ArnhemLeeuwarden kennelijk uit van dezelfde reikwijdte. Hoewel de doorstart van Heiploeg was voorbereid met een beoogd curator, is de OVO-regeling naar het oordeel van het hof niet van toepassing op de doorstart. Door het hof wordt van belang geacht dat uit de omstandigheden van het geval bleek dat de procedure is ingeleid met het oog op liquidatie van het vermogen van Heiploeg. Daarnaast is naar het oordeel van het hof van belang dat op het moment van de faillietverklaring nog geen overeenstemming was bereikt over de doorstart. Die overeenstemming werd in de nacht na de faillietverklaring bereikt. $^{62}$ Tot slot oordeelt ook de Rechtbank Gelderland dat de OVO-regeling niet van toepassing is op een doorstart waaraan geen stille voorbereidingsfase vooraf is gegaan. Hoewel de rechtbank overweegt dat geen sprake is van een prepacksituatie zoals aan de orde was in het Smallsteps-arrest, volgt uit de

57. Verburg 2018, p. 119 en L.G. Verburg, Smallsteps: over de vraag of de gewone doorstart uit faillissement nog toekomst heeft, FIP 2017/334. In FIP is Verburg over prepacks wat terughoudender ('De vraag naar de betekenis van Smallsteps voor de pre-packs die hebben plaatsgevonden is nog geenszins beslist') dan in het INSOLAD Jaarboek (waar hij stelt dat '(...) de regelgeving op het gebied van de overgang van onderneming (...) onverkort op de pre-pack van toepassing is (...)').

58. I. Spinath, De beperkte reikwijdte van het Smallsteps-arrest, $\mathrm{MvO} 2017$, afl. 10-11, p. 253-256. Zie ook I. Spinath, Niet wrijven in de vlek. Reactie op J.M.W. Pool, 'De eerste toepassingen van Smallsteps in Nederland', TvI 2018/53.

59. N.W.A. Tollenaar, De implicaties van Estro voor de pre-pack en WCO I, TvI 2018/6.

60. Rb. Noord-Holland 12 oktober 2017, ECLI:NL:RBNHO:2017:8423 (Bogra), r.o. 5.8 en 5.9.

61. Hof Amsterdam 10 juli 2018, ECLI:NL:GHAMS:2018:2339 (Bogra), r.o. 3.7-3.9.

62. Hof Arnhem-Leeuwarden 17 juli 2018, ECLI:NL:GHARL:2018:6539, r.o. 2.10-2.12. beschikking niet (duidelijk) welke reikwijdte Smallsteps heeft naar het oordeel van de rechtbank. ${ }^{63}$

In september 2018 wees de Rechtbank Limburg een beschikking waarin de OVO-regeling wel van toepassing werd verklaard op de prepack inzake PGV B.V. De rechtbank overweegt weliswaar dat PGV in staat van faillissement verkeerde, maar uit de omstandigheden van het geval blijkt naar het oordeel van de rechtbank dat het doel van de prepack continuïteit van de onderneming was. De doorstart werd gerealiseerd door drie zustervennootschappen van PGV. Dat deze vennootschappen tijdens de stille voorbereidingsfase een indicatief bod uitbrachten, wijst er volgens de rechtbank sterk op dat binnen het concern niet de intentie bestond om het vermogen van de schuldenaar te liquideren. Daarbij wordt overwogen dat het 'de kantonrechter in hoge mate [bevreemdt] dat er binnen de dochtermaatschappijen van het concern enerzijds kennelijk wél de financiële middelen bestond[en] om na faillissement een doorstart te realiseren terwijl er anderzijds niet voor is gekozen om de benodigde financiële impuls te geven teneinde PGV in haar hoedanigheid van distributiecentrum te behouden'. ${ }^{64}$ Het lijkt erop dat de frustratie hierover (mede) tot de conclusie heeft geleid dat de OVO-regeling in onderhavig geval van toepassing was, maar dat neemt niet weg dat de Rechtbank Limburg een andere uitleg geeft aan Smallsteps dan bijvoorbeeld het Hof Arnhem-Leeuwarden in de Heiploeg-zaak.

Dat er onduidelijkheid heerst over de betekenis en reikwijdte van Smallsteps, lijkt ertoe te hebben geleid dat de prepack niet meer wordt toegepast. Wat de uitkomst en reikwijdte van Smallsteps zouden moeten zijn op basis van de tekst van de richtlijn, eerdere jurisprudentie van het Hof en het formele doel van de prepack, is voor de praktijk minder relevant. Het Hof van Justitie heeft immers geoordeeld en slechts een nadere duiding van Smallsteps door het Hof zelf kan de nodige duidelijkheid en zekerheid bieden. Met Spinath en Tollenaar ben ik van mening dat het doel van de prepack hetzelfde is als het doel van een 'gewoon' faillissement. Op basis van de tekst van artikel 5 lid 1 van de OVO-richtlijn en eerdere jurisprudentie van het Hof van Justitie was de conclusie dat de doorstart van Estro onder de uitzondering van artikel 5 lid 1 van de OVOrichtlijn valt dan ook goed te rechtvaardigen. Het Hof heeft echter anders geoordeeld. Met het signaal dat het Hof afgeeft in Smallsteps, lijkt het erop dat de OVO-richtlijn in beginsel van toepassing is op de prepack. Het is te begrijpen dat de praktijk hier in ieder geval van uitgaat. Een belangrijke vraag is daarom of de prepack op dit moment nog relevantie heeft.

\section{Relevantie stille voorbereidingsfase na Smallsteps}

De minister geeft in zijn brief van 11 april 2018 aan dat er in ieder geval twee situaties zijn waarin de stille voorbereidingsfa-

63. Rb. Gelderland 1 februari 2018, ECLI:NL:RBGEL:2018:447 (Tuunte), r.o. 4.8 .

64. Rb. Limburg 26 september 2018, ECLI:NL:RBLIM:2018:9137, r.o. 3.17-3.20 (het citaat komt uit r.o. 3.19) 
se relevant blijft. Ten eerste kan het liquidatieproces worden voorbereid zonder de intentie van een doorstart en in de tweede plaats kan een doorstart worden voorbereid als het hoe dan ook de bedoeling is dat al het personeel overgaat naar de doorstarter. ${ }^{65}$ In het tweede geval is een voordeel van de prepack dat het personeel direct met de faillietverklaring ervan op de hoogte is dat het overgaat naar de doorstarter. Daarmee krijgt de doorstarter niet - of minder - te maken met het probleem dat gekwalificeerd personeel op korte termijn elders aan de slag gaat. ${ }^{66}$ Met name in tijden van krapte op de arbeidsmarkt is dit voordeel aanwezig. Als al het personeel moet worden overgenomen, kan de prepack in sommige gevallen dus nog steeds relevant zijn. Uit paragraaf 2 volgt echter dat het erop lijkt dat de prepack nauwelijks meer wordt gebruikt sinds het Smallsteps-arrest. Dit wijst erop dat de situaties die de minister noemt zich nauwelijks voordoen, en/of dat de prepack nauwelijks gebruikt wordt in deze situaties.

Met het voorgaande is niet alles gezegd, omdat ook als de OVO-regeling van toepassing is niet al het personeel in dienst hoeft te treden bij de verkrijger. Uit artikel 4 lid 1 van de OVO-richtlijn volgt dat de overgang van de onderneming voor de vervreemder of verkrijger geen reden mag zijn voor ontslag. Deze regel is in Nederland gecodificeerd in artikel 7:670 lid 8 BW. Wel volgt uit artikel 4 lid 1 van de OVOrichtlijn dat werknemers ontslagen mogen worden als er economische, technische of organisatorische redenen (ETO-redenen) zijn die wijzigingen voor de werkgelegenheid met zich brengen. In de Nederlandse wet is dit niet gecodificeerd, maar desalniettemin zijn ETO-redenen ook in Nederland een grond voor ontslag. ${ }^{67}$

Niet alleen de verkrijger (bij een prepack de doorstarter), maar ook de vervreemder (bij een prepack de curator) mag werknemers ontslaan wegens ETO-redenen. ${ }^{68}$ Ontslag door de doorstarter heeft als nadeel dat deze een transitievergoeding verschuldigd is aan ontslagen werknemers. ${ }^{69}$ Dit nadeel speelt niet als de curator werknemers ontslaat. In dat geval is immers geen transitievergoeding verschuldigd op grond van artikel 7:673c lid $1 \mathrm{BW}$. Een ander voordeel van ontslag door de curator is dat niet afgespiegeld hoeft te worden binnen het personeelsbestand van de doorstarter. ${ }^{70}$ Dit betekent dat uitsluitend personeelsleden in dienst van de vervreemder worden ontslagen en het ontslag het personeel dat de doorstarter al in dienst heeft niet treft. Tot slot heeft ontslag door de curator

65. Kamerstukken II 2017/18, 34218, J, p. 4-5.

66. Van Hees 2014; Graham 2014, p. 23; V. Finch \& D. Milman, Corporate insolvency law. Perspectives and principles, Cambridge: Cambridge University Press 2017, p. 374 en 375, zie ook p. 658.

67. A.R. Houweling e.a. (red.), Loonstra \& Zondag. Arbeidsrechtelijke themata I, Den Haag: Boom juridisch 2018, p. 558 (hierna: Houweling e.a. 2018a).

68. HvJ EG 12 maart 1998, ECLI:EU:C:1998:99 (Dethier), r.o. 37.

69. Van Zanten 2018, p. 67, 68 en 71-73.

70. Vgl. Houweling e.a. 2018a, p. 562. Zie over afspiegeling en mogelijke uitzonderingen hierop in het algemeen A.R. Houweling (red.) e.a., Loonstra \& Zondag. Arbeidsrechtelijke themata II, Den Haag: Boom juridisch 2018, p. 126-133. als voordeel voor de doorstarter dat hij geen toestemming aan het UWV hoeft te vragen voor ontslag wegens bedrijfseconomische omstandigheden. Dit bespaart de doorstarter tijd en kosten.

De mogelijkheid tot ontslag wegens ETO-redenen biedt op dit moment echter geen redding voor de prepack. Momenteel gaat ontslag wegens ETO-redenen gepaard met rechtsonzekerheid, omdat uit de Nederlandse rechtspraak niet eenduidig volgt wanneer sprake is van ETO-redenen. ${ }^{71}$ Over de prepack en ETO-redenen is nog geen rechtspraak, maar de literatuur is hierover verdeeld. Volgens Tollenaar zijn ETO-redenen in een (prepack)faillissement altijd aanwezig. Naar zijn mening kan de curator alle werknemers ontslaan en is het aan de doorstarter om werknemers opnieuw in dienst te nemen. ${ }^{72} \mathrm{Hufman}^{73}$ en $\mathrm{Zaal}^{74}$ geven aan dat in een faillissement eerder sprake is van een ETO-reden, maar niet per definitie. ${ }^{75}$

De door Tollenaar voorgestane ruime toepassing van ontslag wegens ETO-redenen lijkt niet aan te sluiten bij jurisprudentie van het Hof van Justitie, vooral niet als de doorstart voor faillissement is beklonken. In het Bork-arrest overweegt het Hof namelijk dat bij de beoordeling of sprake is van ETOredenen gekeken moet worden naar de omstandigheden van het geval. Een belangrijke omstandigheid die kan leiden tot de conclusie dat geen sprake is van ETO-redenen, is dat het ontslag 'nagenoeg gelijktijdig met de overgang is ingegaan en dat de betrokken werknemers door de verkrijger opnieuw in dienst zijn genomen'. ${ }^{76}$ Weliswaar stelt A-G Lens in de conclusie vóór het Dethier-arrest dat het feit dat de vennootschap op het moment van ontslag in staat van vereffening verkeerde, doet vermoeden dat sprake is van een ETO-reden, maar in de Dethier-casus waren de werknemers niet weer in dienst genomen door de verkrijger. ${ }^{77}$

De onzekerheid over ontslag wegens ETO-redenen bij de prepack wordt versterkt doordat het lange tijd kan duren voordat de doorstarter zekerheid heeft over de geldigheid van het ontslag. Ontslagen werknemers hebben immers op grond van artikel 7:681 BW een termijn van twee maanden om een verzoek in te dienen bij de kantonrechter tot vernietiging van de opzegging van de arbeidsovereenkomst of toekenning van een billijke vergoeding. Tegen de beslissing van de kantonrechter

71. Houweling e.a. 2018a, p. 559-562.

72. Tollenaar 2018

73. Hufman 2017, p. 188.

74. I. Zaal, De (on)mogelijkheid van ontslag en wijziging bij een pre-packovergang, TvI 2018/5.

75. De benadering van Hufman en Zaal lijkt in een artikel dat zij gezamenlijk hebben geschreven (zie noot 51) echter ruimer, zie Hufman \& Zaal 2014, p. 172: 'Naar onze mening zal in het geval van een (prepack)doorstart in het algemeen sprake zijn van economische, technische of organisatorische redenen, omdat de onderneming van de vervreemder daadwerkelijk in betalingsmoeilijkheden zal verkeren en de kosten van het personeel vaak hoog zijn.'

76. HvJ EG 15 juni 1988, ECLI:EU:C:1988:308 (Bork), r.o. 18.

77. Conclusie A-G Lenz vóór HvJ EG 12 maart 1998, ECLI:EU:C: 1996:291, par. 61 en 62 . 


\section{Maandblad}

Ondernemingsrecht

staan hoger beroep en cassatie open. Deze onzekerheid zal worden verdisconteerd in de prijs die een doorstarter voor de onderneming wil betalen. Gelet op het voorgaande leidt de mogelijkheid tot ontslag wegens ETO-redenen niet tot meer gebruik van de prepack. De onduidelijkheid over de toepasbaarheid van ontslag wegens ETO-redenen zal hiervoor moeten worden weggenomen. In de volgende twee paragrafen wordt, mede aan de hand van Engels recht, onderzocht of de prepack nieuw leven ingeblazen kan worden door de OVOregeling van toepassing te laten zijn op alle doorstarts in faillissement. Daarbij wordt mede ingegaan op de mogelijkheid tot ontslag wegens ETO-redenen.

\section{Overgang van onderneming en administration in Engeland}

Uit de vorige paragrafen is gebleken dat de prepack nauwelijks meer wordt toegepast sinds het Smallsteps-arrest is gewezen. Belangrijke oorzaken hiervan zijn de onduidelijkheid die bestaat over de reikwijdte van Smallsteps en de rechtsonzekerheid die ontstaat bij ontslag wegens ETO-redenen. Ook makt Nederland geen gebruik van de optie die artikel 5 lid 2 van de OVO-richtlijn biedt, waardoor de doorstarter aansprakelijk is voor vorderingen van overgegane werknemers die voor of tijdens faillissement zijn ontstaan, en kunnen arbeidsvoorwaarden niet worden aangepast. De belangrijkste reden dat de prepack niet meer gebruikt wordt, is dat er een goed alternatief bestaat. Als vanuit een onvoorbereid faillissement een doorstart wordt gerealiseerd, is de OVO-regeling op grond van artikel 7:666 BW niet van toepassing. Verschillende auteurs doen de aanbeveling om de OVO-regeling van toepassing te verklaren in faillissement en gebruik te maken van de mogelijkheid tot verzachting die artikel 5 lid 2 van de OVOrichtlijn biedt. ${ }^{78}$ De minister heeft in januari 2019 aangegeven op korte termijn met een voorontwerp te komen voor een OVO-regeling in faillissement. ${ }^{79}$

In Engeland is de OVO-regeling al langere tijd van toepassing op een doorstart in administration, een insolventieprocedure waarvan reorganisatie het hoofddoel is. Ook is de mogelijkheid van ontslag wegens ETO-redenen opgenomen in Engelse regelgeving en is in Engeland gebruik gemaakt van de mogelijkheid van artikel 5 lid 2 van de OVO-richtlijn. In deze paragraaf onderzoek ik daarom de OVO-regeling in administration. Aan de hand van deze beschrijving van het Engelse recht worden in de volgende paragraaf knelpunten gesignaleerd die spelen als de OVO-regeling van toepassing wordt verklaard op alle Nederlandse faillissementen. Ook wordt in de volgende paragraaf, mede aan de hand van de beschrijving van het Engelse recht, een aanzet gedaan om deze knelpunten op te lossen. Voordat de OVO-regeling in administration wordt besproken, ga ik in op de mogelijkheid tot ontslag in administration.

78. Zie noot 6 voor verwijzingen.

79. Kamerstukken I 2018/19, 34218, K

\subsection{Ontslag in administration}

De benoeming van een administrator heeft op zichzelf geen gevolgen voor de arbeidsovereenkomst. De arbeidsovereenkomst eindigt eerst wanneer deze rechtsgeldig is beëindigd. ${ }^{80}$ Voor opzegging van een arbeidsovereenkomst geldt een wettelijke opzegtermijn. Partijen kunnen (zowel bij het sluiten van de arbeidsovereenkomst als bij de beëindiging van de arbeidsovereenkomst) afspreken dat een ontslagvergoeding (payment in lieu of notice - PILON) wordt betaald als de opzegtermijn niet in acht wordt genomen. ${ }^{81}$ Zegt de administrator de arbeidsovereenkomst op terwijl hij de opzegtermijn niet in acht neemt en ook geen PILON is overeengekomen, dan pleegt hij wanprestatie (breach of contract). Vanwege deze wanprestatie is schadevergoeding verschuldigd wegens wrongful dismissal, maar de arbeidsrelatie komt direct tot een einde. ${ }^{82}$ Daarnaast hebben werknemers die ten minste twee jaar in dienst zijn op grond van de Employment Rights Act 1996 Part X recht op een redundancy payment.

De administrator heeft veertien dagen om te besluiten of hij de arbeidsovereenkomst al dan niet overneemt (adoption of contract). Beëindigt de administrator de arbeidsovereenkomst niet in de veertien dagen na zijn benoeming, dan heeft hij in de regel de arbeidsovereenkomst overgenomen. ${ }^{83}$ Daarmee is de vordering tot betaling van loon dat verschuldigd is vanaf het moment van adoption een superpreferente boedelvordering. ${ }^{84}$ Deze vordering komt in rang voor het salaris van de administrator. ${ }^{85}$ Zegt de administrator de arbeidsovereenkomst op nadat hij de overeenkomst heeft overgenomen, dan levert de schadevergoeding die verschuldigd is wegens wrongful dismissal echter geen superpreferente boedelvordering op. ${ }^{86}$

\subsection{Overgang van onderneming en administration}

In het Verenigd Koninkrijk is de OVO-richtlijn gecodificeerd in de Transfer of Undertakings (Protection of Employment) Regulations 2006 (TUPE Regulations). Op grond van TUPE Regulation 4 gaan de rechten van werknemers bij een overgang van onderneming automatisch over op de verkrijger. Uit

80. Lord Browne-Wilkinson in House of Lords 16 maart 1995, [1995] 2 A.C. 394 (Powdrill v Watson).

81. Section 86 Employment Rights Act 1996.

82. Lord Browne-Wilkinson in House of Lords 12 maart 1992, [1992] 1 A.C. 687 (Delany v Staples). Zie ook Pumfrey J in High Court of Justice (Chancery Division) 25 juli 2007, [2007] I.C.R. 1688 (Re Leeds United Football Club).

83. Lord Browne-Wilkinson in House of Lords 16 maart 1995, [1995] 2 A.C. 394 (Powdrill v Watson). Zie voor een uitzondering Laddie J in High Court of Justice (Chancery Division) 7 mei 2003, [2003] EWHC 1339 (Ch) (Re Antal International Limited), waar de administrator niet wist dat de werknemers een arbeidsovereenkomst hadden met de schuldenaar.

84. Wat rang betreft vergelijkbaar met de vordering uit hoofde van onverschuldigde betaling die tijdens faillissement ontstaat, waarbij de betaling het gevolg is van een onmiskenbare vergissing: HR 5 september 1997, NJ 1998/437 (Ontvanger/Hamm q.q.), r.o. 3.4.

85. Insolvency Act 1986 Sched. B1, par. 99.

86. Court of Appeal 10 augustus 2005, [2006] I.C.R. 205 (Krasner v McMath). Zie ook Pumfrey J in High Court of Justice (Chancery Division) 25 juli 2007, [2007] I.C.R. 1688 (Re Leeds United Football Club). 
TUPE Regulation 7 volgt dat de overgang niet de enige of voornaamste reden (sole or principal reason) voor ontslag mag zijn. Ook is hierin opgenomen dat werknemers wel ontslagen kunnen worden als de enige of voornaamste reden voor ontslag een ETO-reden is. TUPE Regulations 4 en 7 zijn op grond van TUPE Regulation 8(7) niet van toepassing als de vervreemder is verwikkeld in een faillissementsprocedure of soortgelijke procedure met het oog op de liquidatie van het vermogen van de vervreemder.

Het primaire wettelijke doel van de administrator is om ervoor te zorgen dat de vennootschap en de onderneming die de vennootschap drijft er weer bovenop komen. Vaak is het niet mogelijk om dit doel te bereiken. ${ }^{87}$ De administrator moet dan streven naar een beter resultaat voor de schuldeisers dan bij een ontbinding (wounding up). Is ook dat doel niet bereikbaar, dan moet de administrator ervoor zorgen dat een uitkering gedaan kan worden aan een of meer zekerheidsgerechtigde of preferente crediteuren. ${ }^{88}$ Omdat het primaire doel van administration is gelegen in de continuïteit van de vennootschap en de daaraan verbonden onderneming, oordeelde de Court of Appeal in 2011 dat (pre-pack) administration een insolventieprocedure is die niet het oog heeft op de liquidatie van het vermogen van de vervreemder. Ook als vóór opening van de administration al duidelijk is dat het primaire doel niet behaald kan worden, heeft de administration als procedure niet liquidatie van het vermogen van de vervreemder als doel. De Court of Appeal verkoos in deze uitspraak de 'absolute approach' boven de 'fact based approach'. ${ }^{89}$

De OVO-regeling is hiermee altijd van toepassing op een doorstart vanuit administration. Wel is artikel 5 lid 2 van de OVO-richtlijn in Engeland geïmplementeerd. Vorderingen die zijn ontstaan voor de overgang en vergoed worden uit het National Insurance Fund, gaan niet over op de verkrijger (TUPE Regulation 8(5)). Vorderingen die niet voor vergoeding in aanmerking komen, gaan wél over op de verkrijger. Over het algemeen gaat het grootste deel van de vorderingen niet over, maar een probleem is dat de verkrijger niet weet voor welke vorderingen hij aansprakelijk wordt. ${ }^{90}$

\subsection{Ontslag wegens de overgang en ETO-redenen ${ }^{91}$}

De onrechtmatigheid van ontslag wegens overgang van onderneming en de ETO-redenen zijn gecodificeerd in TUPE Regulation 7 en nader uitgewerkt in de rechtspraak. Voordat TUPE Regulation 7 werd aangepast in 2014, stond in TUPE

87. K. van Zwieten, Goode on principles of corporate insolvency law, Londen: Sweet \& Maxwell 2018, par. 11-24.

88. Insolvency Act 1986 Sched. B1, par. 3.

89. Court of Appeal 20 december 2011, [2011] EWCA Civ 1567 (Key2Law (Surrey) LLP v De'Antiquis).

90. Finch \& Milman 2017, p. 658 en 659.

91. Zie voor een rechtsvergelijking met Engeland ook W.H.A.C.M Bouwens, W.L. Roozendaal \& D.M.A. Bij de Vaate, Werknemers en insolventie. Een rechtsvergelijkende studie naar de rechtspositie van werknemers bij insolventie van de werkgever, Amsterdam VU 2015, bijlage bij Kamerstukken II 2014/15, 33695, 9, p. 107-117.
Regulation 7 dat een ontslag onrechtmatig is (unfair dismissal) als de enige of voornaamste reden voor het ontslag de overgang zelf is of een reden die gelieerd is aan (connected with) de overgang, tenzij sprake is van een ETO-reden. Om de tekst van TUPE Regulation 7 meer aan te laten sluiten bij de OVOrichtlijn is geschrapt dat een ontslag onrechtmatig is als de reden gelieerd is aan de overgang. ${ }^{92}$ Het is nog onduidelijk welke betekenis in de rechtspraak toegekend wordt aan deze wijziging, maar in de literatuur wordt gesteld dat het mogelijk is dat een ontslag alleen onrechtmatig is als op het moment van ontslag duidelijk is wie de verkrijger is van de onderneming. ${ }^{93}$

Voor de wijziging van TUPE Regulation 7 was geoordeeld dat ontslag ook onrechtmatig kan zijn op grond van TUPE Regulation 7(1), als de verkrijger nog niet bekend was. In 2011 oordeelde de Court of Appeal in Spaceright dat een ontslag in strijd kan zijn met TUPE Regulation 7(1) als de onderneming nog niet is verkocht. Als een administrator een werknemer ontslaat om de onderneming aantrekkelijker te maken voor potentiële verkrijgers, is sprake van een connectie tussen het ontslag en de overgang en kan geen beroep worden gedaan op een ETO-reden. ${ }^{94}$ In de motivering van Briggs LJ zijn de woorden connected with uit TUPE Regulation 7(1) (oud) van groot belang. Het is daarom de vraag of Spaceright onder de gewijzigde TUPE Regulation 7 tot dezelfde uitkomst geleid zou hebben. ${ }^{95}$

In Crystal Palace wordt uitgebreider ingegaan op de ETOredenen. In de casus die tot deze uitspraak leidde, ontsloeg de administrator een deel van het personeel om voortzetting van de onderneming en uiteindelijk een doorstart mogelijk te maken. Omdat de administrator niet in staat was om alle loonkosten te voldoen, moest hij een deel van het personeel ontslaan om liquidatie te voorkomen. Hiermee was het ontslag gerechtvaardigd, omdat sprake was van een economische reden die wijzigingen voor de werkgelegenheid met zich bracht. ${ }^{96}$ Dat het uiteindelijke doel van de administrator het realiseren van een doorstart was, doet hier niet aan af. Als afgegaan zou worden op het uiteindelijke doel van de administration, zou een beroep op een ETO-reden vrijwel nooit slagen. Daarom moet worden gekeken naar de reden van de adminis-

92. Department for Business Innovation \& Skills (BIS), Explanatory Memorandum to the Collective Redundancies and Transfer of Undertakings (Protection of Employment) (Amendment) Regulations 2014, 2014, No. 16, par. 7.3.

93. J. McMullen, TUPE: Ringing the (wrong) changes. The Collective Redundancies and Transfer of Undertakings (Protection of Employment) (Amendment) Regulations 2014, Industrial Law Journal 2014, afl. 2, p. 149-169 en A. Serr, Insolvency and TUPE update, Insolvency Intelligence 2014, afl. 5, p. 72-74.

94. Mummery LJ in Court of Appeal 14 december 2011, [2011] EWCA Civ 1565 (Spaceright Europe Ltd v Baillavoine and others).

95. Serr 2014, p. 72-74.

96. Maurice Kay LJ in Court of Appeal 13 november 2013, [2013] EWCA Civ 1410 (Crystal Palace FC Ltd v Kavanagh). 


\section{Maandblad}

Ondernemingsrecht

trator voor een specifiek ontslag en niet naar het uiteindelijke doel dat hij heeft in administration. ${ }^{97}$

In een eerdere uitspraak, Dynamex, werd door de Court of Appeal al geoordeeld dat gekeken moet worden naar de reden van de werkgever voor het ontslag. In administration wordt de werkgever, de vennootschap, vertegenwoordigd door de administrator. De overwegingen van de administrator zijn daarom leidend voor het antwoord op de vraag of het ontslag gerechtvaardigd is door een ETO-reden. Heeft de administrator een economische reden voor het ontslag, dan is niet relevant dat de administration door het voormalige management is verzocht met het doel om een doorstart aan een gelieerde partij te realiseren. Uiteraard moet de administrator wel daadwerkelijk een economische reden hebben voor het ontslag en mag er geen sprake zijn van samenspanning met het management. $^{98}$

\section{Overgang van onderneming in faillissement}

Mede aan de hand van de beschrijving van het Engelse recht uit de vorige paragraaf wordt in deze paragraaf een aantal knelpunten gesignaleerd als de OVO-regeling van toepassing verklaard wordt op alle Nederlandse faillissementen. Ook wordt een aantal voorwaarden geschetst waaraan een dergelijke regeling moet voldoen. Naar aanleiding van deze knelpunten en voorwaarden wordt een aanzet gegeven voor een OVOregeling in faillissement.

\subsection{Einde arbeidsovereenkomst en opzegtermijn}

De curator moet bij het beëindigen van een arbeidsovereenkomst een opzegtermijn in acht nemen. Op grond van artikel 7:672 lid 2 sub a BW geldt een opzegtermijn van een maand indien de arbeidsovereenkomst op het moment van opzegging korter dan vijf jaar heeft geduurd. Heeft de arbeidsovereenkomst langer dan vijf jaar geduurd, dan geldt op grond van artikel 6:672 lid 2 BW een langere opzegtermijn. In faillissement wordt de opzegtermijn op grond van artikel $40 \mathrm{Fw}$ gemaximeerd op zes weken. De arbeidsovereenkomst eindigt op de dag waartegen de overeenkomst is opgezegd. Dit is een knelpunt als de OVO-regeling van toepassing wordt verklaard in faillissement.

Wordt een doorstart gerealiseerd vóór het einde van de datum waartegen een arbeidsovereenkomst is opgezegd, dan gaat ook de werknemer van wie de arbeidsovereenkomst is opgezegd over naar de doorstarter voor de duur van de opzegtermijn. ${ }^{99}$ Dit leidt ertoe dat deze resterende vordering feitelijk een superpreferente boedelvordering wordt, omdat de doorstarter de hoogte van deze vordering in mindering brengt op de prijs die hij bereid is te betalen voor de onderneming. Deze korting

97. Briggs LJ in Court of Appeal 13 november 2013, [2013] EWCA Civ 1410 (Crystal Palace FC Ltd v Kavanagh).

98. Court of Appeal 17 april 2008, [2008] EWCA Civ 381 (Amicus and others v Dynamex Friction Ltd and another) (met dissenting opinion van Lawrence Collins LJ).

99. HR 21 april 1995, NJ 1995/671. Zie ook Houweling e.a. 2018a, p. 531. op de koopprijs kan een doorstart in de weg staan. Dit is het geval als de prijs die de doorstarter door aftrek van de korting wil betalen lager is dan de prijs die gerealiseerd kan worden bij stuksgewijze verkoop van de onderdelen van de onderneming. ${ }^{100}$

In Engeland is dit probleem er niet, omdat arbeidsovereenkomsten worden opgezegd zonder inachtneming van de opzegtermijn. Het is ook verstandig dat de administrator de opzegtermijn niet in acht neemt, omdat loon van werknemers na veertien dagen in beginsel in rang voor zijn eigen salaris komt. Ook in Nederland is het mogelijk om een arbeidsovereenkomst op te zeggen zonder opzegtermijn. Op grond van artikel 7:672 lid $10 \mathrm{BW}$ is dan een schadevergoeding verschuldigd aan de werknemer die gefixeerd is op het loon over de opzegtermijn. Een schadevergoeding die gefixeerd is op het loon over de opzegtermijn, valt onder de loongarantieregeling. 101 Toch brengt het een risico met zich als een curator zich niet houdt aan de opzegtermijn. Een curator handelt namelijk opzettelijk in strijd met de wet als hij de opzegtermijn niet in acht neemt, wat tot gevolg heeft dat hij in beginsel persoonlijk (pro se) aansprakelijk is. ${ }^{102}$ De curator loopt dus een aansprakelijkheidsrisico als hij de opzegtermijn niet in acht neemt bij opzegging van een arbeidsovereenkomst.

Een mogelijke oplossing voor dit knelpunt is om een nieuw lid in artikel $40 \mathrm{Fw}$ op te nemen, waarin staat dat de curator bevoegd is de arbeidsovereenkomst op te zeggen tegen een eerdere dag dan tussen partijen geldt, onverminderd artikel 7:672 lid 10 BW. De curator moet deze bevoegdheid - met machtiging van de rechter-commissaris op grond van artikel 68 lid 3 Fw - behouden als hij de arbeidsovereenkomst reeds opgezegd heeft met inachtneming van de geldende opzegtermijn. In artikel $40 \mathrm{Fw}$ moet dan ook worden opgenomen dat de vervangende schadevergoeding in de zin van artikel 7:672 lid 10 BW een boedelschuld is. Uit het oogpunt van duidelijkheid en rechtszekerheid zou daarnaast expliciet in artikel 64 Werkloosheidswet (WW) kunnen worden opgenomen dat deze vordering onder de loongarantieregeling valt. ${ }^{103}$

De SER signaleerde het hier genoemde knelpunt ook al in 1985 en gaf in zijn advies aan dat de door mij voorgestane oplossing gecompliceerd is. De SER gaf de voorkeur aan een regeling waarin werd opgenomen dat werknemers van wie het dienstverband rechtsgeldig door de curator is opgezegd, uitge-

100. J. Armour \& S. Deakin, Insolvency and employment protection: The mixed effects of the Acquired Rights Directive, International Review of Law and Economics 2002, afl. 4, p. 443-463. Zie ook Tollenaar 2011.

101. CRvB 18 februari 1992, RSV 1992/222; P.R.W. Schaink, Loongarantie bij faillissement, ArbeidsRecht 1996/43.

102. Laatstelijk HR 9 november 2018, NJ 2018/464 m.nt. F.M.J. Verstijlen. Zie ook HR 16 december 2011, NJ 2012/515 m.nt. F.M.J. Verstijlen (Prakke/Gips).

103. Volgens een advies van de SER uit 1985 zou dit noodzakelijk zijn, Advies overgang van ondernemingen (SER-advies 85/23 van november 1985 aan de ministers van Justitie en van Sociale Zaken en Werkgelegenheid), Den Haag: SER 1985, p. 21 (hierna: SER 1985). Het SERadvies is echter gegeven voor CRvB 18 februari 1992, RSV 1992/222. 
sloten zijn van automatische overgang van de overeenkomst op de verkrijger. ${ }^{104}$ Volgens mij is de door mij geschetste oplossing redelijk eenvoudig. Daarnaast is het de vraag of de door de SER voorgestane oplossing door de beugel van de OVO-richtlijn kan. De arbeidsovereenkomst bestaat immers nog op het moment van de overgang, waarmee de rechten en verplichtingen die uit de arbeidsovereenkomst voortvloeien op grond van artikel 3 lid 1 van de OVO-richtlijn overgaan op de verkrijger. De richtlijn biedt niet de mogelijkheid om in een insolventieprocedure ontslagen werknemers niet over te laten gaan.

\subsection{Opzegmoment}

Curatoren plegen arbeidsovereenkomsten direct na de faillietverklaring op te zeggen met inachtneming van de wettelijke opzegtermijn. ${ }^{105}$ Het is ook van belang dat de curator dit doet, omdat werknemers anders het risico lopen dat ze voor een deel van de opzegtermijn geen beroep kunnen doen op de loongarantieregeling. Het UWV betaalt op grond van artikel 64 lid 2 WW het loon over maximaal dertien weken voorafgaand aan de datum dat de dienstbetrekking redelijkerwijs had moeten eindigen. Daarbij mag het UWV er in beginsel van uitgaan dat de arbeidsovereenkomst op de faillissementsdatum wordt opgezegd. ${ }^{106}$

Zolang op de faillissementsdatum niet duidelijk is of een doorstart zal plaatsvinden, ontslaat de curator in beginsel alle werknemers met het oog op de loongarantieregeling. Daarmee handelt de curator niet in strijd met het opzegverbod van artikel 7:670 lid $8 \mathrm{BW}$. De reden voor het ontslag is namelijk niet de overgang van de onderneming, maar het feit dat een deel van de loonvordering van werknemers in beginsel niet overgenomen wordt door het UWV bij een later ontslag. Dat de curator na opzegging van de arbeidsovereenkomst een doorstart zal beproeven, doet hier niet aan af. ${ }^{107}$ Is op de faillissementsdatum wel duidelijk dat een doorstart zal plaatsvinden die kwalificeert als een overgang van onderneming, dan kan de loongarantieregeling niet de reden voor ontslag zijn. De curator weet dan immers dat de arbeidsovereenkomsten overgaan op de verkrijger, zodat de curator de werknemers niet hoeft te ontslaan. In dat geval is het opzegverbod van artikel 7:670 lid 8 BW wel aan de orde en kunnen werknemers alleen ontslagen worden als sprake is van een ETO-reden.

Het knelpunt is dat er op deze wijze nog steeds een verschil is tussen de prepack en het onvoorbereide faillissement in de feitelijke uitwerking van de OVO-regeling. Wil een gelieerde partij een doorstart realiseren, dan kan zij de automatische overgang van werknemers tegenhouden door haar doorstart-

104. SER 1985, p. 21.

105. H. van Steenbergen, Het karakter van de loongarantieregeling, in: E.J.R. Verwey, M.A. Broeders \& Ph.W. Schreurs (red.), De curator en het personeel (INSOLAD Jaarboek 2018), Deventer: Wolters Kluwer 2018, p. 240.

106. CRvB 27 mei 2009, USZ 2009/194.

107. Vgl. Court of Appeal 13 november 2013, [2013] EWCA Civ 1410 (Crystal Palace FC Ltd v Kavanagh). plannen niet direct met de curator te delen. Zoals de Court of Appeal oordeelde in Dynamex, ${ }^{108}$ is mijns inziens ook naar Nederlands recht in het kader van het ontslagverbod wegens overgang van onderneming en het ontslag wegens ETO-redenen doorslaggevend wat de beweegredenen van de curator zijn. Deelt een gelieerde partij haar doorstartplannen pas met de curator nadat werknemers zijn ontslagen, dan verandert dat niet de reden van het ontslag door de curator. Om de OVOregeling daadwerkelijk tot haar recht te laten komen in faillissement, moet een oplossing worden gevonden voor dit knelpunt.

Geïnspireerd door Engels recht zou de curator veertien dagen de tijd kunnen krijgen om te onderzoeken of een doorstart tot de mogelijkheden behoort. Is in deze periode een doorstart gerealiseerd, dan kan de curator binnen deze veertien dagen werknemers ontslaan als hier ETO-redenen voor zijn. Het overige personeel gaat over op de verkrijger. Is in deze periode geen doorstart gerealiseerd, dan kan de curator alle werknemers ontslaan. Als de opzegtermijnen gelijk blijven, zal de loongarantieregeling uitgebreid moeten worden met de veertien dagen bedenktijd van de curator. De curator is dan niet gedwongen om direct na de faillietverklaring alle arbeidsovereenkomsten op te zeggen. Een probleem van deze oplossing is dat de boedelschulden hoger zijn als de curator binnen veertien dagen geen doorstart heeft gerealiseerd en de arbeidsovereenkomsten alsnog moet opzeggen met een opzegtermijn van maximaal zes weken. Dit is strijdig met het belang van de gezamenlijke schuldeisers. Een andere mogelijkheid is om de bedenktijd van de curator af te trekken van de opzegtermijn, maar dat strijdt met het belang van de werknemers. Bij de oplossing die hier is geschetst, moet dus een (politieke) afweging worden gemaakt tussen het belang van de boedel en het belang van de werknemers.

Een tweede mogelijke oplossing is om te regelen dat voor toepassing van de OVO-regeling in faillissement uitgegaan wordt van de fictie dat de curator geen werknemers heeft ontslagen. Ook werknemers van wie de arbeidsovereenkomst rechtmatig is opgezegd, gaan dan automatisch over op de verkrijger als de doorstart kwalificeert als overgang van onderneming. Dit leidt slechts uitzondering als aangetoond kan worden dat de opzegging ook rechtmatig zou zijn als de overgang op het moment van ontslag al bekend was, omdat sprake is van een ETOreden. De rechter-commissaris is de aangewezen persoon om te beoordelen of sprake is van een ETO-reden. ${ }^{109}$ Ten aanzien van de ontslagvolgorde kan worden aangeknoopt bij het afspiegelingsbeginsel ${ }^{110}$ of (andere) geobjectiveerde selectiecriteria die zijn goedgekeurd door de rechter-commissaris. ${ }^{111}$ Complementair hieraan kan een herplaatsingsverplichting gel-

108. Court of Appeal 17 april 2008, [2008] EWCA Civ 381 (Amicus and others v Dynamex Friction Ltd and another).

109. Vgl. W.H.A.C.M. Bouwens, W.L. Roozendaal \& D.M.A. Bij de Vaate, De doorstart in rechtsvergelijkend perspectief, TAP 2016/172; Bouwens 2018; Hufman 2017.

110. Zo onder meer de bronnen die genoemd zijn in de vorige noot. 111. Verburg 2018, p. 139-140. 


\section{Maandblad}

Ondernemingsrecht

den die vergelijkbaar is met artikel 7:681 lid 1 sub d BW. ${ }^{112}$ De doorstarter moet dan de werknemers die op basis van de geldende ontslagvolgorde als laatst voor ontslag in aanmerking kwamen, een arbeidsovereenkomst aanbieden onder de gebruikelijke arbeidsvoorwaarden als binnen 26 weken na de doorstart een vacature ontstaat.

Zeker als de doorstarter een herplaatsingsverplichting heeft, kan de toetsing van ETO-redenen door de rechter-commissaris summier zijn. Als de curator in samenspraak met de doorstarter aannemelijk maakt dat een specifiek aantal werknemers nodig is om de overgedragen onderneming efficiënt en winstgevend te drijven, kunnen de overige werknemers ontslagen worden wegens ETO-redenen. Zowel de curator als de doorstarter heeft er belang bij om het aantal personeelsleden dat nodig is om de onderneming te drijven over te laten gaan op de doorstarter. De curator heeft hier belang bij omdat daarmee de boedelschulden afnemen. Het belang van de doorstarter is gelegen in behoud van het meest gekwalificeerde personeel. Heeft de doorstarter immers na twintig weken een vacature, dan moet hij een door de curator ontslagen werknemer alsnog in dienst nemen. Over het algemeen zullen goed gekwalificeerde werknemers op korte termijn een nieuwe baan hebben, waardoor de doorstarter het moet doen met kennelijk minder gekwalificeerde werknemers.

De tweede oplossing is eenvoudiger dan de eerste. Een ander voordeel van de tweede oplossing is dat het arbeidsrecht dat geldt in faillissement niet verandert als er geen doorstart plaatsvindt. Ook is er geen onderscheid meer tussen de voorbereide doorstart en de onvoorbereide doorstart, omdat het ontslag door de curator direct na faillietverklaring weggedacht wordt. De prepack kan daarmee weer relevant worden, omdat er in arbeidsrechtelijke behandeling geen onderscheid meer is tussen de prepack en de gewone doorstart.

\subsection{Artikel 5 lid 2 OVO-richtlijn}

Voorstellen in de literatuur om de OVO-regeling in faillissement van toepassing te verklaren, gaan altijd gepaard met het voorstel om gebruik te maken van de mogelijkheden die artikel 5 lid 2 van de OVO-richtlijn biedt. ${ }^{113}$ Op grond van dit lid kunnen lidstaten regelen dat schulden die zijn ontstaan voor de overgang van de onderneming in een insolventieprocedure niet overgaan op de verkrijger, en dat arbeidsvoorwaarden in samenspraak met de vertegenwoordigers van werknemers gewijzigd kunnen worden.

Hiervoor heb ik aangegeven dat in Engeland het overgrote deel van de bestaande schulden niet overgaat, maar schulden gaan wel over op de verkrijger als deze niet vergoed worden door het National Insurance Fund. Dit is een knelpunt, omdat de verkrijger niet altijd weet waarvoor hij aansprakelijk wordt. Zeker als de administratie van de failliet gebrekkig is, kan een curator deze informatie niet met zekerheid verschaf-

112. Zoals voorgesteld in Bouwens, Roozendaal \& Bij de Vaate 2016. 113. Zie ook voor overige verwijzingen onder meer Bouwens 2018. fen. Het risico dat de doorstarter loopt op aansprakelijkheid voor oude schulden, drukt de prijs die de doorstarter bereid is te betalen voor de onderneming. Dit knelpunt kan worden opgelost door in de Nederlandse regeling te bepalen dat geen enkele schuld die is ontstaan voor de doorstart overgaat op de verkrijger.

\section{Conclusie}

Naar aanleiding van twee brieven van de minister voor Rechtsbescherming is in deze bijdrage onderzocht of de prepack nog relevantie heeft na Smallsteps. Voor de Smallsteps-uitspraak was de prepack al een marginaal verschijnsel, maar daarna vinden er vrijwel geen prepacks meer plaats. De reden hiervoor is dat onzekerheid bestaat over de reikwijdte van Smallsteps. Regelmatig wordt in de literatuur het standpunt ingenomen dat de OVO-regeling van toepassing is op alle prepacks. In de praktijk wordt daarom gekozen voor de veiligere weg: de doorstart vanuit een faillissement dat niet is voorbereid. Daarmee is mede gelet op de discussie in de literatuur de kans immers kleiner dat de OVO-regeling van toepassing wordt geacht door een rechter.

Daarnaast is, om de prepack nieuw leven in te blazen en omdat de minister heeft aangegeven binnenkort met een voorontwerp te komen, mede aan de hand van Engels recht, onderzocht welke knelpunten het Nederlandse recht kent voor toepassing van de OVO-regeling op alle faillissementen. Ook is een aanzet gegeven om deze knelpunten weg te nemen. De reden om de prepack nieuw leven in te blazen is dat uit empirisch onderzoek volgt dat de prepack zorgt voor meer behoud van werkgelegenheid, terwijl de prepack niet negatief is voor de boedel. Als de OVO-regeling zonder meer van toepassing wordt verklaard op alle faillissementen, zorgt dat voor een aantal knelpunten.

Een eerste knelpunt is dat werknemers die rechtsgeldig zijn ontslagen, overgaan op de doorstarter voor de duur van de opzegtermijn die resteert op het moment van de overgang van de onderneming. Dit kan in de weg staan aan een doorstart. Een mogelijke oplossing voor dit knelpunt is om in artikel 40 Fw te regelen dat de curator bevoegd is om met machtiging van de rechter-commissaris de overeenkomst op te zeggen tegen een eerdere dag dan tussen partijen geldt. De werknemer heeft dan recht op schadevergoeding die gefixeerd is op het loon over de opzegtermijn. Voor de duidelijkheid zou expliciet kunnen worden geregeld dat het UWV deze vordering overneemt onder de loongarantieregeling.

Ten tweede staat aan een effectieve werking van de OVOregeling in faillissement in de weg dat curatoren arbeidsovereenkomsten direct na de faillietverklaring opzeggen. Zolang geen doorstart is voorbereid voor faillissement, is een dergelijk ontslag niet in strijd met het opzegverbod wegens overgang van onderneming van artikel 7:670 lid $8 \mathrm{BW}$. Dit probleem kan worden opgelost door voor toepassing van de OVOregeling in faillissement uit te gaan van de fictie dat de curator 


\section{Maandblad}

Ondernemingsrecht

geen werknemers heeft ontslagen. Werknemers gaan dan automatisch over op de doorstarter, tenzij sprake is van een ETOreden. Door daarnaast een herplaatsingsverplichting op te leggen aan de doorstarter heeft deze een prikkel om het aantal werknemers over te nemen dat daadwerkelijk nodig is voor het drijven van de onderneming. Tot slot is het van belang om in de wet op te nemen dat de doorstarter niet aansprakelijk wordt voor schulden die zijn ontstaan voor de doorstart, en moet het mogelijk zijn om arbeidsvoorwaarden aan te passen in samenspraak met de vertegenwoordigers van werknemers. 